\title{
男性逐年検診受診者における各程生活習慣病検査值の 経時的变化について
}

段 佳之 ${ }^{1} 、$ 小林 廉毅 ${ }^{2}$

${ }^{1}$ 医潦法人社団 あさひ会 東プラクリニック、 ${ }^{2}$ 東京大学大学院医学系研究科 公恶衛生学

【はじめに】職域検診を逐年で受診している受診者では，種々の桙查結果を経時的に観察できる利点がある。 今回施設検診において個々の受診者について各種生活習慣病の検查值が 1 年のスパンでいかに变化するかに ついて観察した。【対象ならびに方法]平成 14 年度 (3326 名) と平成 15 年度（3271 名）に当院で検診を受 診した男性受診者から，2560 名（年齢 $47.9 \pm 11.0$ 才）の逐年検診受診者を抽出した。うち 2433 名で逐年の 血液検查データが得られた。受彰者を平成 14 年時点の BMIにより肥満度別に分類した。また 1 年間の各検 查值の增減をデルタ $(\Delta)$ で表示する。各受診者の体重增減（ $\Delta$ 体重）を元にして，「減少群」( $2 \mathrm{~kg}$ 以上の 減少), 「増加群」(2kg 以上の增加),「不変群」(体重增減 $2 \mathrm{~kg}$ 末満) に更に分類し, 体重の変動が各生活習 慣病検查値（体脂肪率，最高血圧，総コレステロール，中性脂肪，HDL-chol，空腹時血糖，HbA1c，尿酸， GPT, $r$ GTP，NCEP-ATP III 改スコア (=代謝症候群指数)）の変化に及ほす影響について観察した。また 各指標のデルタ $(\Delta)$ を元に相関分析を行い，同時に「連れて動く」複数の指標の存在について観察した。 【結果】男性 2560 名の $\Delta$ 体重は-0.04 $\pm 2.28 \mathrm{~kg}$ で, 隇少/增加不变が 385/375/1800 名であった。体脂肪率, NCEP-ATP III 改スコア以外では, 「軽度肥満」の「体重減少」群で収縮期血圧, 中性脂肪, HDL-chol, GPT, $\gamma$ GTPについて, 有意の改善方向への経時的変化が見られた。相関分析では $\Delta$ 体重は， $\Delta$ 空腹時血糖ならび に $\Delta$ 尿酸を除いた他の指標のデルタと, $\mathrm{r}=0.1$ から 0.2 の弱い相関が見られた。 $\Delta$ HDL-chol については， $\Delta$ 体重や $\Delta$ 中性脂肪との間に $\mathrm{r}=-0.25$ の弱い負の相関が見られた。また各検查值と自身のデルタ $(\Delta)$ との 間に $r=-0.2$ から-0.3 程度の相関が見られたことから, 「平均への回唚」(regression to the mean) の現象も観 察された。はとめ】 general population を対象とした場合には，1年の短いスパンで多くの生活習慣病指標が 体重の变化と連動して変動することが示された。これは指導を行う際の努力目標，あるいは介入後の効果判 定の際の指針となる可能性が考えられた。空腹時血糖，尿酸については体重の变化と連動する傾向は見られ なかった。

\begin{tabular}{l|cccccc} 
& $\Delta$ 体重 & $\Delta \mathrm{T}$-chol & $\Delta \mathrm{TG}$ & $\Delta \mathrm{HDL}-\mathrm{C}$ & $\Delta \mathrm{FBS}$ \\
\hline$\Delta$ 体重 & 1 & $0.20 *$ & $0.14 *$ & $-0.22 *$ & 0.05 \\
$\Delta \mathrm{T}$-chol & - & 1 & $0.45 *$ & $0.22 *$ & $0.11 *$ \\
$\Delta \mathrm{TG}$ & - & - & 1 & $-0.24 *$ & 0.01 \\
$\Delta \mathrm{HDL}-\mathrm{C}$ & - & - & - & 1 & 0.00 \\
$\Delta \mathrm{FBS}$ & - & - & - & - & 1
\end{tabular}

